\title{
Improving Customer Service in the Banking Industry-Case of Ghana Commercial Bank (GCB)-Ghana
}

\author{
George K Amoako \\ Department of Marketing, Central Business School, Central University College \\ P. O. Box 2305, Tema, Greater Accra, Ghana
}

Tel: 233-20-262-0174Ｅ-mail: gako2001us@yahoo.com

Received: December 29, 2011

Accepted: February 7, $2012 \quad$ Published: April 1, 2012

doi:10.5539/ibr.v5n4p134

URL: http://dx.doi.org/10.5539/ibr.v5n4p134

\begin{abstract}
Customer service has become so vital and significant to consider especially in the financial business sector whether locally or globally. As banks continue to provide an increasing number of financial services and products, they face the challenge of integrating these disparate systems into a coherent, efficient infrastructure, while delivering the highest level of customer service and convenience without exposing their customers to the bank's internal system integration problems. However, banks in Ghana especially Ghana Commercial Bank (GCB) needed to improve and formalize its customer service and public relations programs. A descriptive research method was used to gather data from the respective target population. Customer service at GCB from the customers' perspective is not satisfactory but has led to the increase in number of new customers, maintenance of existing customer and increase in profitability among others.
\end{abstract}

Keywords: Customer service, Improving, GCB, Banking

\section{Introduction}

During the past decade, the financial sector in Ghana has undergone major changes mainly through the financial sector structural adjustment programme as part of the economic recovery programme. Moreover, globalisation, mergers and acquisitions, and the emergence of new technologies have contributed dramatically to stiffer competition and pressures on profitability. In such a competitive marketplace, attracting profitable customers is a priority of all the financial institutions' (FI) managers especially banks. Banks are profit-seeking institutions that must provide acceptable returns to shareholders (Agyapong, Agyapong \& Darfor, 2011).

The banking industry in Ghana has come under intense competition in the past ten years. This is due partly to new entrants into the industry both local and foreign and enforcement of Bank of Ghana regulations. High service quality is therefore required to differentiate offerings in the market place. Good customer service will only be defined by the experience of the bank customers. The question is what is required to attract, maintain and excite customers in the banking sector in Ghana.

Customers are the heart of every successful business and therefore businesses need to more concentrate on customers more than ever. Except those who donate blood voluntarily, one is either selling a service or a product for a living. Politicians, bankers, clerks, messengers, bus conductors, mortuary attendant, ticket agents, market women and everyone who provides a trade or service has a customer. According to Scott (2002), Customer service is a series of activities designed to enhance the level of customer satisfaction, that is, the feeling that a product or service has met the customer expectation. The level of satisfaction can also vary depending on other options the customer may have and other products against which the customer can compare the organization's products.

\subsection{Industry in Ghana}

Some of the main challenges in customer service in banking includes poor data base management of customers, illiteracy level of majority of customers, lack of adequate infrastructure and technology on which customer satisfaction depends on like electricity (for ATM operations), low level of internet penetration. The importance of technology in banking became obvious when developed countries that had involved IT in its banking operations managed to reduce their costs of operations (Daily Graphic, 2008). Banks in Ghana gradually introduced technology into its operations in the late 1980s to enhance their operations and to help clients enjoy their services with much convenience. Various researches have indicated that technology influences banking in a positive way in terms of productivity, cashiers' work, banking transactions, bank patronage, bank services delivery, customers' services and 
bank services (Balachandher et al., 2001; Idowu et al., 2002; Hunter, 1991; Yasuharu, 2003). Owusu-Frimpong (1999), other factors that customers are looking for in a high customer service can be divided into two broad groups as tangible and intangible factors. The tangible factors may concern performance, quality, reliability, cost of services and convenience. The intangible factors may be reputation, sense of caring, courtesy, willingness to help, problem solving ability of staff, etc. The tangible and the intangible factors primarily drive home the point about customer's perception about how he/she is being treated by a bank. Is the bank being fair to him/her in matters of interest rates, penalties, service charges and that he/she has not to fear any hidden costs and charges at a later date. Further, the customer also draws comfort from the fact that he or she is not being discriminated against vis-à-vis a new customer.

Lack of data integration in the industry does not encourage industry growth. In fact, customer service is a challenging issue in any service industry as there are many intangibles that define a customer's satisfaction or otherwise with a particular bank / branch / product or process. The advertisement and marketing campaigns that seem to evoke heightened customer response would come to zero if the service standards do not match the perceived quality aspirations of the customers.

From the point of view of an overall sales process engineering effort, customer service plays an important role in an organization's ability to generate income and revenue (Don \& Rogers, 2008). The benefits of the current customer-centric banking industry are phenomenal. The banks are able to differentiate themselves from the competition and improve their image in the eyes of the customer.

From the above perspective, customer service should be included as part of an overall approach to systematic improvement in banking activities because the customers decide whether the survival of banks in Ghana thus the researchers quest to investigate how the customer service can be improved in the Ghanaian banking industry with reference to Ghana Commercial Bank. The objectives of the research were as follows:

a) To examine the awareness of GCB in the banking industry.

b) To find out if the target market is aware of the offerings of GCB.

c) To examine the attitudes of the target market towards GCB in relations to its image and reputation alongside that of its competitors.

d) To identify areas where GCB needs to improve on its image in the industry.

\section{Literature Review}

A service is any act or performance that one party can offer to another that is essentially intangible and does not result in the ownership of anything (Kotler \& Keller, 2006). The insight of service marketing focuses on selling the services in the best interest of sers/customers. It is fretful with a scientific and planned management of services which makes possible a fair management of the interests of providers as well as the users. Services are vital segment of all economies and they become increasingly more everyday life as economies develop. The size of service sector is increasing day-by day generally in all types of economies in the World and in particular developing economies. This is an exhilarating time for services development, since new technologies are transforming the services worldwide. These elementary and speedy changes being practiced by services markets throughout the world are brought about among other factors primarily by the technological improvements and by competition oriented reform policies. This creates different anticipation on customers' awareness towards the product or service of the company. In the era of globalization and borderless market, responsiveness, quality and productivity are essential for the survival and growth of any organization (Potluri \& Mangnale, 2011). Despite this huge transformation and improvement in the service sector and particularly banking sector in Ghana, it still remains a fact that less than $20 \%$ of Ghanaians form the banking population as opposed to the $80 \%$ unbanked population (Fanawopo, 2007). Gronroos (2000) defined service as, "A service is a process consisting of a series of more or less intangible activities that normally, but not necessarily always, take place in interactions between the customer and service employees and/or physical resources or goods and/or systems of service provider, which are provided as solutions to customer problems". Fogli (2006) defined term service quality as "a global judgment or attitude relating to particular service; the customer's overall impression of the relative inferiority or superiority of the organization and its services".

\subsection{Service Interaction}

Interactions between customers and employees are a decisive component of service quality. This is principally factual for services exemplified by a high degree of person-to-person interaction and by the absence of an exchange of tangible goods. The client comes away from service interaction with feelings of contentment or annoyance. Service encounter is an interpersonal association between the firm's staff and customers (Potluri \& Mangnale, 2011). Research has indicated that service quality has been increasingly recognized as a critical factor in the success of any business (Parasuraman et al., 1988), and the banking industry in this case in not exceptional (Hossain \& Leo, 2009). 
Service quality has been widely used to evaluate the performance of banking services (Cowling \& Newman, 1995). The banks understand that customers will be loyal if they provide greater value (quality services) than their competitors (Dawes \& Swailes, 1999), and on other hand, banks can only earn high profits if they are able to position themselves better than competitor within specific market (Davies et al., 1995). Consequently, banks need to focus on service quality as a core competitive strategy (Chaoprasert \& Elsey, 2004).

\subsection{Service Quality}

Service Quality involves a comparison of expectations with performance. According to Lewis and Booms (1983) service quality is a measure of how well a delivered service matches the customers' expectations. Generally, the customer is requesting a service at the service interface where the service encounter is being realized; then the service is being provided by the provider and in the same time delivered to or consumed by the customer.

The main reason to focus on quality is to meet customer needs while remaining economically competitive in the same time. This means satisfying customer needs is very important for the enterprises to survive. The outcome of using quality practices is:

- Understanding and improving of operational processes.

- Identifying problems quickly and systematically.

- Establishing valid and reliable service performance measures.

- Measuring customer satisfaction and other performance outcomes.

Organizations are increasingly interested in retaining existing customers while targeting non-customers and customers of competitors; measuring customer satisfaction provides an indication of how successful the organization is at providing products and/or services to the marketplace. According to Rose and Hudgins (2008), a bank is a financial intermediary that offers the widest range of financial services especially credit, savings, and payment services and performs the widest range of financial functions of any business firm in the economy. The functions of a bank according to Reed and Gill (1989), include Creating Money, Payments Mechanism, Pooling of Savings, Extension of Credit, Facilities for the Financing of Foreign Trade, Trust Services, Safe keeping of Valuables and Brokerage Services. Universal banks offer the full range of banking services, together with non banking financial services, under one legal entity. In addition, the banks have direct links between banking and commerce through cross shareholders and shared directorships. Their financial activities normally include intermediation and liquidity via deposits and loans as well as trading of financial instruments (e.g., bond, equity, currency) and associated derivative, Stock broking, Corporate advisory services, including mergers and acquisitions, Investment management and Insurance (Heffernan, 2005). GCB provides a wide range of products and services for the benefit of its customers. From the traditional products of the Current/Savings Accounts, GCB now offers specialized products and services including Link2Home for Ghanaians resident abroad, doorstep cash collection, loans and overdrafts. There are also investments products like treasury bills as well as fixed and call deposits. These are cut to suit the individual needs of customers. In addition, GCB has taken advantage of an enhanced information technology system, to introduce Internet Banking (Commernet Plus), Royal Banking, Smart Pay (Fee Payments), Kudi Nkosuo, GCB Inland Express Money Transfer, International Money Remittance Payments, GCB Kidistar Account and MasterCard (Note 1).

However, a bank like GCB recognize that customer satisfaction (CS) plays a key role in a successful business strategy. What is unclear is the exact nature of that role, how precisely satisfaction should be managed, and whether managerial efforts aimed at increasing satisfaction lead to higher score in sales. Today, managers in the banking sector especially at Ghana Commercial Bank (GCB) undertake substantial efforts to conduct CS surveys. Yet it appears that in most cases the data are used to simply monitor specific attributes, and especially overall satisfaction, over time. Unless the impact of customer satisfaction on revenues is assessed, managers have little basis for allocation of resources.

The concept of customer care is concern with customer satisfaction putting the customer first, anticipating needs and problems, tailoring the product and services to meet needs and being nice to customers it also includes service to the customer, delivery operation, employee relationship with customer and internal relationship between employee and management. In improving customer care strategies and programs, financial services organizations are managing products and services, delivery systems, environment and people so as to provide an efficient and caring service, getting things right the first time and maintaining standards (Naveed, 2009). In services industries, the subject of service quality globally remains a critical one as service providers strive to maintain a comparative advantage in marketplace. Financial services in general, particularly banks; compete in marketplace with generally undifferentiated services and products, thereby service quality becomes a key competitive weapon (Stafford, 1996). A banking organization like GCB can only differentiate itself from competitors by providing high quality services. It is true that structural changes have resulted in banks to perform a greater range of activities, and enabling them to become more 
competitive with non-bank financial institutions (Angur et al., 1999). Presently, technological advancements are causing banks to revise their strategies for services offered to both individual and commercial customers.

\subsection{Quality Measurement}

Quality measurement is separated in subjective and objective processes, at which mostly the customers' satisfaction is being measured. Measuring the customers' satisfaction is an indirect way to measure quality.

Objective processes are being subdivided into primary and secondary processes:

- During primary processes, test buyings from silent shoppers are being made or normal customers are being watched.

- During secondary processes quantifiable enterprise numbers like amount of complaints or the amount of given back goods are being analyzed, and with this information conclusions to quality can be drawn.

- Subjective processes are being subdivided into characteristic orientated, incident orientated and problem orientated processes.

- To the characteristic focused processes counts the SERVQUAL method.

- To the incident focused processes counts the Critical Incident Theory.

- To the problem focused processes counts the Frequenz Relevanz Analyse (German).

The most important and most used process to measure service quality is the SERVQUAL method.

In the early 1990s, the banking system included the central bank (the Bank of Ghana), three large commercial banks (Ghana Commercial Bank, Barclays Bank of Ghana, and Standard Chartered Bank of Ghana), and seven secondary banks. These and the commercial banks placed short-term deposits with two discount houses set up to enhance the development of Ghana's domestic money market: Consolidated Discount House and Securities Discount House, established in November 1987 and June 1991, respectively. At the bottom of the tier were 100 rural banks, which accounted for only 5 percent of the banking system's total assets. Loans rose, with banks' claims on the private sector up by 24.1 percent, to $\phi 117.4$ billion (Note 2 ).

However, the Ghanaian Banking Industry has witnessed many developments in terms of innovative products and services. This current state of affairs has brought tremendous transformation in the way business is done in the banking industry. The deregulation of the sector and subsequent introduction of a universal banking license for banks to engage in all banking transactions ranging from merchant banking, commercial and investment banking to development activities has been a catalyst in this direction. The 21 st century is considered as the service industry century. Service industry is growing at a rapid pace across developed and developing countries. Services are deeds, processes and performances (Zeithaml \& Bitner, 2003). Broadly speaking, services include all economic activities whose output is not a physical product or construction is generally consumed at the time it is produced and provides added value in forms (convenience, amusement, timeliness, comfort or health) that are essentially intangible concerns of its first purchaser (Quinn \& Paquette, 1987). Service has been entering every part of life from the most essential demands (such as eating, sleeping) to other entertainment needs such as banking, sport, traveling, cooking and telecommunication). Customer service improvement has led to the introduction of innovative products of banks as acknowledged by Koch and MacDonald (2006) can be financial or technical. For example, such emerging financial products as personal housing mortgage loans, personal consumption loans, sale and trusteeship of funds have not only satisfied people's diversified financial demands to some extent but also expanded banks' operational spaces and their profit-making channels. According to Koch (2006), financial innovation is the catalyst behind the evolving financial services industry and the restructuring of financial markets. Innovations take the form of new securities and financial markets, new products and services, new organizational forms and new delivery systems. Institutions may modify the means by which they offer products and services. Recent trends incorporate technological advances with development of cash management accounts, including the use of ATM, home banking via computer and the internet, and shared national and international electronic transfer systems.

Most of the service providers in Ghana behave as if they are doing their customers favors instead of rendering a service which is promised and paid for. Customer service has lost its impetus, for it is no longer an index measuring success of service providers. Customers have been pushed to the wall to accept the fact that as far as Ghana is concerned, the customer has no choice or voice other than to survive at the mercy of halfhearted service providers. Poor customer service is gradually becoming an accepted norm in our society (Adu-Gyamfi, 2008).

Customer expectations and needs for services have substantially increased (Wrennall, 2000). As customers become better educated, they demand new products, better and more reliable delivery as well as more responsive services. As a consequence, to improve competitiveness, banks have to understand customer needs and expectations (Parasuraman, 1991) and satisfy their customers by providing better products and services. In using the traditional Servqual model in 
assessing service quality research done by (Khalid, Mahmood, Abbas \& Hussain, 2011) in Pakistan indicated that in the assessment of service quality customer perceive highest satisfaction in the responsiveness area and lowest in the tangibles area. They found out that in order to achieve higher levels of service quality, the bank managers should redesign their strategies about customer satisfaction with respect to service quality.

According to Adu-Gyamfi (2008), the following are some of the causes of poor customer service in Ghana with regards to businesses:

- We do not teach it in our schools and business world.

- It is not respected by employers and co-workers to be customer service -oriented employee.

- One need to go extra mile in cultivating customer service, unfortunately most employers and employees are lazy.

The increased emphasis on quality improvement has led organizations to emphasize customer service. In almost any job especially the banking sector, customer service skills are important to achieving success and people skills form the foundation for good customer service. Such skills include interpersonal relation, problem solving, leadership and teamwork. People skills can foster a positive attitude, effective communication, courteous and respectful interaction and the ability to remain calm in control of difficult situations (Becker \& Wellins, 1990).

Likewise, customer service training organization-wide can be a key component of a bank turnaround. As so many banks are striving to become increasingly customer-centric in order to survive and grow. Achieving this customer focus requires leveraging existing customer information to gain a deeper insight into the relationship a customer has with the institution, and improving customer service related processes so they are quick, error-free, and convenient for the customer. According to the American Bankers Association, the average cost to acquire a new customer in a bank in the United States is $\$ 3,500$. As a consequence of these high costs, retaining and growing the existing customer base becomes increasingly important. However, the realization of this in Ghana coupled mergers, acquisitions, and regulation changes has resulted in the banking industry increasing the number of services it provides to include more than just deposit and withdrawal to meet its customer-centric status (Microsoft in Financial Services, 2003).

In the same vein, banks cannot rule out the role of technology in customer service. Adoption of technology has changed the face of the banking sector which is manifest in the various transformational developments of the recent past. The benefits of technology are, however, not commensurate with the developments. The speed, cost, convenience and efficiency of banking services have not improved by factors that technology enables one to achieve. This, if banks can bring in cost-effective technology with appropriate delivery model, it would improve speed, efficiency and quality of banking services. It will also ensure that customers are treated fairly as technology has this unique characteristic of bringing in equity (BIS Review, 2010).

BIS Review 2010 outlined that banks must also resolve to reduce customer grievances by minimizing courtesy and behavioral standards, transparency, non-discriminatory policy, deliver what is promised and many. The function of service quality is competitiveness including customer satisfaction (maintain a customer base). It is not necessary that a firm applies all of the 5 main quality criteria as indicated in SERQUAL model. Instead the company can emphasize on the ones which are important for its strategy. The bottom line here is that the customer should be satisfied after encounter with the service. In summary, this study was designed to address how customer service is rendered in Ghanaian businesses, how poor these services are provided and how to reduce customer grievances effectively.

\section{Research Methodology}

\subsection{Research Design}

A research design is the program that guides the researchers in the process of collecting, analyzing and interpreting the data. The researcher decided to use the descriptive form of research design to provide solutions to the research problems. Descriptive research involves gathering data that describe events and then organizes, tabulates, depicts, and describes the data collection. This research design is used because it often uses visual aids such as graphs and charts to aid the reader in understanding the data distribution. Because the human mind cannot extract the full import of a large mass of raw data, descriptive statistics are very important in reducing the data to manageable form. Likewise, descriptive research can be either quantitative or qualitative, thus the researchers' choice of research design (Glass \& Hopkins, 1984).

\subsection{Study Population}

Considering the broad nature of the banking industry of Ghana, the complexities involved in customer service and time constraint, the study could not look at improving customer service within all banks in Ghana. As a result the researchers have selected management officials and customers of three Ghana Commercial Bank (GCB) offices within Accra including the head office as the population of the study. The branches are Head Office at Accra Central, 
Kwame Nkrumah Circle Branch, and Kaneshie Branch. These branches were selected because they are very busy branches.

\subsection{Sample Size and Sampling Technique}

The main instrument for data collection was the questionnaire that was administered through the help of some staff of the selected financial institutions.

Researchers normally determine their sample size and technique to validate their objectives of the study. The researchers used stratified sampling method to select respondents made up of management officials and customers of the GCB offices chosen for the study, making a sample of one hundred (100) respondents. The researchers made a clear indication of what the study set to achieve by providing respondents with the objectives of the study, this is to get them informed on hand before attempting to answer questions. However, the stratified sampling method is the process of dividing members of the population thus officials and customers of Ghana Commercial Bank into homogeneous subgroups before sampling was done.

\subsection{Sources of Data}

The research was based on both secondary and primary data collection. The primary sources of data were used purposefully in the analysis stage of the study. This data was gathered through sources such as questionnaires and interview questions designed to solicit information from management officials and customers of Ghana Commercial Bank, Ghana (GCB). Also, the secondary sources of data were gathered from relevant reading materials obtained from the internet, books in journals, articles, magazines, annual report of GCB, newspapers and the internet on issues relating to customer service.

\subsection{Research Instrument}

The researcher used questionnaires as the basic research instrument, which is the collection of questions put together based on the objectives of the study to gather data on the objectives of the study and customer service issues relevant to the study.

\subsection{Analysis of Data}

The researchers used simple Microsoft office excel, with graphical and table presentation for the analyses. In addition, researchers analysed the data by using both qualitative and quantitative data.

\subsection{Research Limitations and Potential Problems in the Industry}

Due to financial and general resource limitation the study was conducted using only one bank (GCB) and also only three branches out of 157 branches and agencies. Also, the sample size and number of actual respondents are limited. The researcher or other researchers may use a bigger sample size to find out more about customer satisfaction and service quality. Finally, a more robust analysis involving other factors is needed in financial service industry to reach at a strong conclusion on customer satisfaction in customer service. The potential problem is that the industry keeps growing and customers' interest and needs keeps increasing in complexity making research into customer needs and wants more complex.

\section{Results}

In analyzing the feedback from respondents, it was evidenced that GCB provides products and services such as loan financing, mortgage financing and many. This is because GCB is the bank in Ghana with the highest capital base because it is owned by the government of Ghana and provides services for a wide range of customers across the country. Again, as to whether officials of GCB give instant feedback to customers on transactions, majority of the respondents view is an indication that customers of GCB are given instant feedback on banking transactions undertaken despite the fact that there are some delays sometimes preventing prompt feedback.

The result on whether from the officials view customers of GCB have knowledge of products and services offered by the bank. $87 \%$ respondents think customers have knowledge of products and services whiles $13 \%$ think otherwise. The findings are an indication that, the bank thinks it has put in place factors that ensures that all customers of the bank are informed about products and service offered. Some of these factors mentioned by respondents (officials of GCB) are media publicity, website publicity, direct marketing and mail box advertisement among others. With the methods used by the bank to create awareness for the banks products and services, GCB rely massively on media advertisement as a form awareness creation for the bank's products and services. With research on classification of tangibles considered by GCB as way of improving customer service, responses made by officials of GCB therefore means that, though there are more tangibles that show the improvement of customer service by GCB, there is still room for improvement in customer service. With analysis of quality of services, majority of the respondent answered that GCB provides unsatisfactory quality services. In analyzing the courteous abilities of Customer Service Representative at 
GCB, management of GCB are putting in a lot of measures to improve on their customer relations practices as a development agenda in this era of stiff competition in the banking sector.

With Knowledge about Products and Services provided by GCB, there was an indication that customers at GCB are aware of majority of products and services offered by GCB.

With Analysis of Whether the Relationship between Officials of GCB and Customers is Cordial, the result is an indication that, although GCB has improved on customer relations, there is more room for improvement as customers must be seen as part owners of the organization. With Reliability of GCB, the responses from respondents showed that all kinds of approaches are applied by employees of GCB to improve the customer relations at the bank to make the bank reliable but customers of the bank are still not satisfied since $60 \%$ of the respondents did not respond to this question.

Again with evidence of customer service at GCB, majority said that officials have the knowledge to answer customer questions and that the customer service of the bank has improved. With Analysis of Perception about Customer Service at GCB, it was nothing to write home about since unsatisfactory weighed very high.

\subsection{Analysis of Respondents Understanding of Customer Service}

Over the last decade, banks have undergone many changes as mergers and acquisitions, and regulatory changes that have shaped the banking industry into one that provides more than just the traditional deposit and loan products. As banks continue to provide an increasing number of financial services and products, they face the challenge of integrating these disparate systems into a coherent, efficient infrastructure, while delivering the highest level of customer service and convenience without exposing their customers to some customer service problems. That is why management, investors and other stakeholders have to take proactive steps to protect the money they put into their banking business by improving customer service.

More so, it is very necessary to find out the understanding of customer service which forms the basis of providing optimum customer service. To receive the required result about the meaning of customer service, the researchers asked officials of Ghana Commercial Bank (GCB) what they know about customer service. The field survey revealed that customer service is a combination of business process and technology that seeks to understand a company's customers from the perspective of who they are, what they do, and what they are like. Other respondents say customer service is the ability to provide a service or product in the way that it has been promised.

Secondly, the field survey disclosed that customer service is about treating others as you would like to be treated yourself and bank's ability to supply their customers' wants and needs based on convenience and time of operation. For example, Commerce Bank, an American most convenient bank opens its branch offices seven days a week. Weekdays it opens at 7:30 a.m. and closes at 8 p.m. with shorter weekend hours. The bank always opens 10 minutes early and stays 10 minutes late. Commerce's astonishing service record has made them one of America's best-performing banks, with their stock increasing 2,000 percent in 10 years. Commerce Bank's positive results from its extreme customer service approach prove the importance of customer service in banking.

\section{Conclusion}

This study investigated the ways that customer service can be improved in the banking sector of Ghana. Ghana Commercial Bank was chosen as a case study and the research concerned the administration of questionnaires to bank officials and customers of the bank in several branches. Various discussions indicated that customers' perceptions vary according to the nature of service at GCB. In this case, the highest customers' perceptions are demonstrated in the tangibles area such as infrastructure facilities of the bank, followed by the empathy area such as timing of the bank and returns on deposit. On the other hand, the lowest perceptions are in the competence area such as the method of imposing service charges followed by reliability.

All categories of respondents such as officials and customers of GCB understand clearly what customer service means. In their discussions, they claimed customer service is a combination of business process and technology that seeks to understand a company's customers from the perspective of who they are, what they do, and what they are like. Others say customer service is the ability to provide a service or product in the way that it has been promised and customer service is about treating others as you would like to be treated yourself and bank's ability to supply their customers' wants and needs based on convenience and time of operation.

The findings also revealed that though customer service at GCB from the customers perspective is not satisfactory, improving customer service at the bank has led to the increase in number of new customers, maintenance of existing customers, increase in loan disbursement, easy and safe payment, increase in profitability, increase in market share, increase in revenue and reduction in expenditure. 
Looking at the results of the study, the researchers recommended some interventions that can be implemented to improve customer service at GCB. Based on the findings and other observation made, the researchers recommended that continuous improvement of the quality of human resources through on the job training is needed. Classify Customer Complaints: as individual complaints are recorded, the nature of the complaint, along with the product or service the complaint is about, requires classification. In the banking sector, complaints that violate federal laws, or internal bank policies and procedures, should be classified separately from other customer service issues. Ghana Commercial Bank should enhance its customer relations management practices to strengthen the cordial relationship between bank officials and customers to create a perception that bank officials are reliable. Ghana Commercial Bank must improve its physical infrastructure such as buildings, furniture, fittings, equipments, vehicles and many to appeal customers since some customers consider them to enhance customer satisfaction. Finally, bank officials in all departments of the Ghana Commercial Bank must be given customer service training to get the understanding of how important customers are to the bank and also an independent unit should be created to handle creation, implementation monitoring and control of customer service strategies of GCB.

\section{Approaches to Improve Service Quality}

Generally the service design or the service delivery can be improved to achieve a high quality service. The service design consists in: service product design, service facility design and service process designated.

The service delivery consists in service delivery process, service encounter environment and customer-Provider interaction.

Improvement of service quality therefore requires that GCB plan around improving the design and delivery of the offerings and thereby improving on quality of customer service.

\section{Acknowlegement}

The author wants to acknowledge Staff and Management of GCB (Head office, Circle and Kaneshie branches) and Akosua Asare- Berko and Eunice Apraku for their support in gathering data for this research.

\section{References}

Adu-Gyamfi, K., (2008). The culture of poor customer service in Ghana. The Way Forward, NJ, USA, Posted By Gap On Tue, 01/08/2008 - 13:23

Agyapong, D., Agyapong, G. K. Q., \& Darfor, N. K. (2011). Criteria for assessing small and medium enterprises' borrowers in Ghana. International Business Research, 4(4), 132-138. http://dx.doi.org/10.5539/ibr.v4n4p132

Angur, M. G., Nataraajan, R., \& Jaherea, J. S. Jr. (1999). Service quality in the banking industry: an assessment of developing economy. International Journal of Marketing, 17(3), 116-125.

Becker, W. S., \& Wellins, R. S. (1990). Customer service perceptions and reality. Training and Development Journal, 44(3), 49-51.

Chaoprasert, C., \& Elsey, B. (2004). Service quality improvement in Thai retail banking and its management Implications. ABAC Journal, 24 (1), 47-66.

Cowling, A., \& Newman, K. (1995). Banking on People. Personnel Review, 24(7), $25-41$. http://dx.doi.org/10.1108/00483489510095789

Davies, F., Moutinho, L., \& Curry, B. (1995). Construction and testing of a Knowledge-based system in retail bank marketing. International Journal of Bank Marketing, 13 (2), 235-260. http://dx.doi.org/10.1108/02652329510078613

Dawes, J., \& Swailes, S. (1999). Retention sans frontiers: Issues for financial services retailers. International Journal of Bank Marketing, 17(1), 36-43. http://dx.doi.org/10.1108/02652329910254037

Fanawopo, S. (2006). World without cash-Nigeria's payment card grows significantly. Retrieved October 15, 2007, from http://www.sunneswsonline.com

Fogli, L. (2006). Customer Service Delivery. San Francisco: Jossey-Bass.

Glass, G. V., \& Hopkins, K. D. (1984). Test Bank for Statistical Methods in Education \& Psychology (2nd ed.) Englewood Cliffs, N.J.: Prentice-Hall. Smith.

Heffernan, R. (2005). Exploring (and explaining) the British Prime Minister. The British Journal of Politics \& International Relations, 7(4), 605-620. http://dx.doi.org/10.1111/j.1467-856X.2005.00203.x 
Hossain, M., \& Leo, S. (2009). Customer perception on service quality in retail banking in Middle East: the case of Qatar. International Journal of Islamic and Middle Eastern Finance and Management, 2(4), 338-350. http://dx.doi.org/10.1108/17538390911006386

Hung, N. B., \& Loan, T. Q. N. (2004). Quality Management. Ho Chi Minh City: National University Public House.

Khalid, S., Mahmood, B., Abbas, M., \& Hussain, S. (2011). Customer satisfaction with service quality in conventional banking in Pakistan. International Journal of Marketing Studies, 3(4), 165-174. http://dx.doi.org/10.5539/ijms.v3n4p165

Kotler, P., \& Keller, K. L. (2006). Marketing Management (pp. 402). New Delhi, India: Prentice-Hall.

Mac Donald, S. S., \& Koch, T. W. (2006). Management of Banking (6th ed.). U.S.A: Thomson - South Western.

Mishkin, F. S., \& Eakins, S. G. (1997). Financial Markets and Institutions (2nd ed.). USA: Addison-Wilsey Longman, Inc.

Muhammad, N. (2009). Customer satisfaction in banking sector. National University of Modern Languages Islamabad. Section. B, pp.1-9. Reviewed from http://www.gcb.com.gh (accessed 02/06/11).

Owusu-Frimpong, N. (1999). Patronage behaviour of Ghanaian bank customers. International Journal of Bank Marketing, 17(7), 335-341.

Parasuraman, A., Zeithaml, V. A., \& Berry, L. L. (1988). SERVQUAL- a multiple-item scale for measuring consumer perceptions of service quality. Journal of Retailing, 64(1), 12-40.

Peppers, D., \& Martha, R. (2008). Rules to Break and Laws to Follow (pp. 24-164). Wiley.

Potluri, R. M., \& Mangnale, V. S. (2011). Critical factors of customer satisfaction in ethiopian service sector. Asian Journal of Business Management, 3(1), 1-7.

Quinn, J. B., Baruch, J. J., \& Paquette, P. C. (1987). Technology in Services. Scientific American, 257(6), 50-58.

Read, E. W., \& Gill, E. K. (1989). Commercial banking (4th ed.). New Jersey: Engle Wood cliffs.

Solomon, M. (2010). Seven Keys to Building Customer Loyalty--and Company Profits. Retrieved from http://www.gcb.com.gh (accessed 29/05/11).

Rose, P., \& Hudgins, S. (2008). Bank Management \& Financial Services (7th ed.). McGraw-Hill /Irwin.

Roth, A. V., \&Van Der Velde, M. (1991). Technology Advantage, Bank Management, 18(2), 14-19.

Stafford, M. (1994). How customers perceive SQ. Journal of Retail Banking, 17(2), 29-38.

Stafford, M. R. (1996). Demographic discriminators of service quality in the banking industry. The Journal of Services Marketing, 10(4), 6-22. http://dx.doi.org/10.1108/08876049610124554

Zeithaml, A., Valarie, B., \& Mary, J. (2003). Services Marketing (3rd ed.). New York: McGraw-Hill.

\section{Notes}

Note 1. Posted: Wednesday, 11th March, 2009, http://www.gcb.com.gh.

Note 2. www.countrystudy.us/ghana/74.htm source, US Library of Congress.

Table 1. Products and Services Provided by GCB

\begin{tabular}{lll}
\hline Products \& Services & Frequency & Percent \\
\hline Automated Teller Machines & 40 & 100 \\
Personal Computer Banking & 40 & 100 \\
Internet Banking & 40 & 100 \\
Telephone Banking & 40 & 100 \\
SME & 40 & 100 \\
Branch Networking & 40 & 100 \\
Corporate Services & 40 & 100 \\
Investment Services & 40 & 100 \\
E-zwich & 40 & 100 \\
TOTAL & 40 & 100 \\
\hline
\end{tabular}

Source: Field Survey (2011). 
Table 2. Tangibles Considered by GCB as a Way of Improving Customer Service

\begin{tabular}{lll}
\hline Tangibles & Frequency & Percent \\
\hline Modern equipment & 10 & 25 \\
Visually appealing facilities & 10 & 25 \\
Officials with neat and professional appearance & 5 & 12.5 \\
Visually appealing materials associated with the service convenience & 5 & 12.5 \\
Business hours & 10 & 25 \\
TOTAL & 40 & 100 \\
\hline
\end{tabular}

Source: Field Survey (2011).

Table 3. Knowledge about Products and Services Provided by GCB

\begin{tabular}{lll}
\hline Products \& Services & Frequency & Percent \\
\hline Automated Teller Machines & 4 & 10 \\
Personal Computer Banking & 8 & 20 \\
Internet Banking & 2 & 5 \\
Telephone Banking & 0 & 0 \\
SME & 10 & 25 \\
Branch Networking & 5 & 12.5 \\
Corporate Services & 4 & 10 \\
Investment Services & 1 & 2.5 \\
E-zwich & 6 & 15 \\
TOTAL & 40 & 100 \\
\hline
\end{tabular}

Source: Field Survey (2011).

Table 4. Reliability of GCB

\begin{tabular}{lll}
\hline Responses & Frequency & Percent \\
\hline Providing service as promised & 5 & 12.5 \\
Dependability in handling customers' service problems & 6 & 15 \\
Performing services right the first time & 3 & 7.5 \\
Keeping customers informed about when services will be performed & 2 & 5 \\
TOTAL & 16 & 40 \\
\hline
\end{tabular}

Source: Field Survey (2011).

Table 5. Evidence of Customer Service at GCB

\begin{tabular}{lll}
\hline Responses & Frequency & Percent \\
\hline Officials instill confidence in customers & 8 & 20 \\
Make customers feel safe in their transactions & 7 & 17.5 \\
Officials are consistently courteous & 4 & 10 \\
Officials have the knowledge to answer customer questions & 21 & 52.5 \\
TOTAL & 40 & 100 \\
\hline
\end{tabular}

Source: Field Survey (2011).

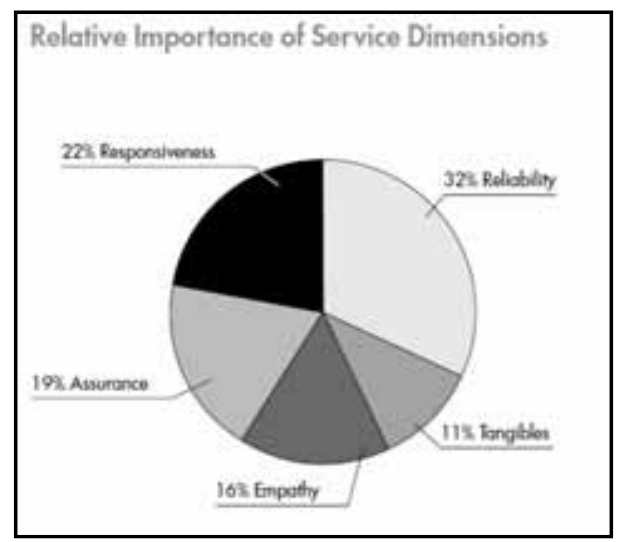

Figure 1. Servqual Model

Source: Bouwman, H (2003) State of the art business models. 


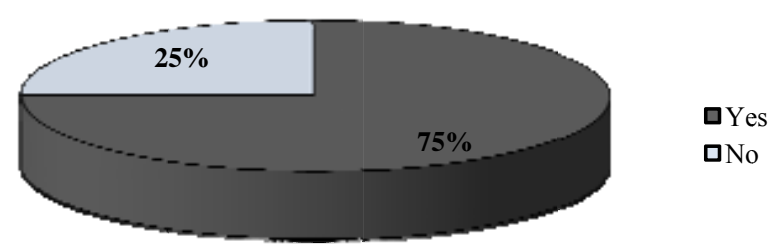

Source: Field Survey (2011).

Figure 2. Analysis of Instant Feedback for Customers

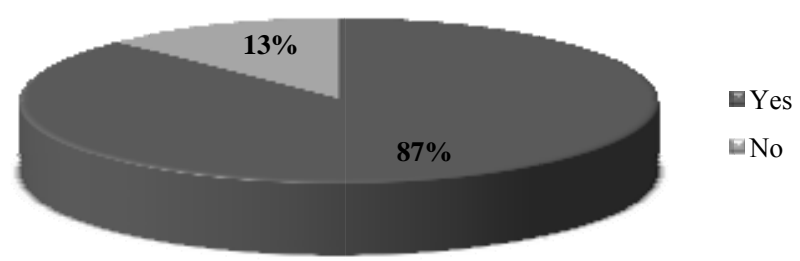

Figure 3. Analysis of Knowledge of the Products and Services of GCB

Source: Field Survey (2011).

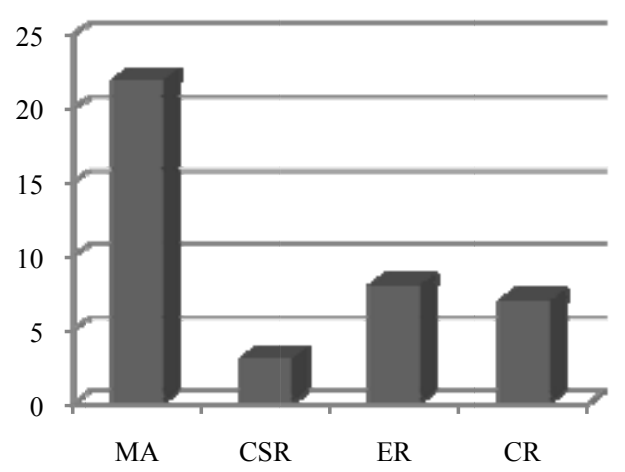

Figure 4. Analysis of Methods Used for Creating Awareness for GCB Products and Services Source: Field Survey (2011).

Note: $M A=$ Media Advertisement, $C S R=$ Corporate Social Responsibility, $E R=$ Employee Referrals, $C R=$ Customer Referrals.

Source: Field Survey (2011).

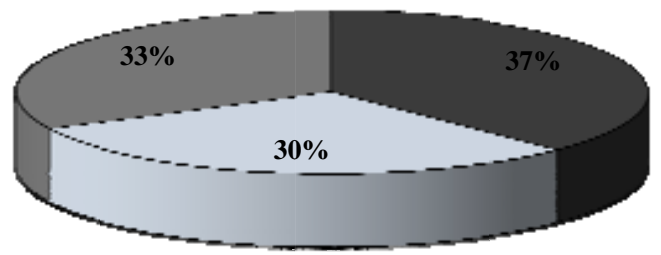

口Push Strategy aPull Strategy $\quad$ BBoth Push and Pull Startegies

Figure 5. Marketing Strategy Employed by GCB 


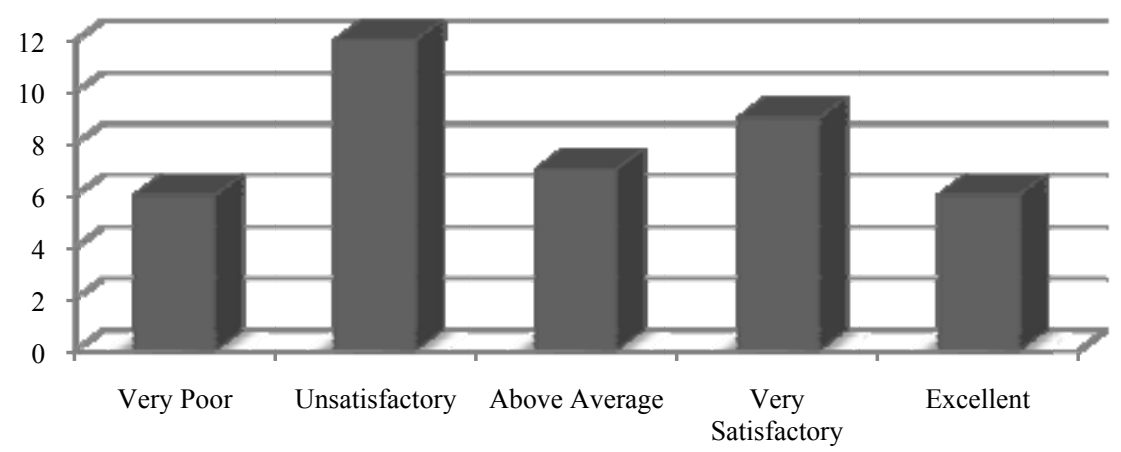

Figure 6. Analysis of the Quality of Service

Source: Field Survey (2011).
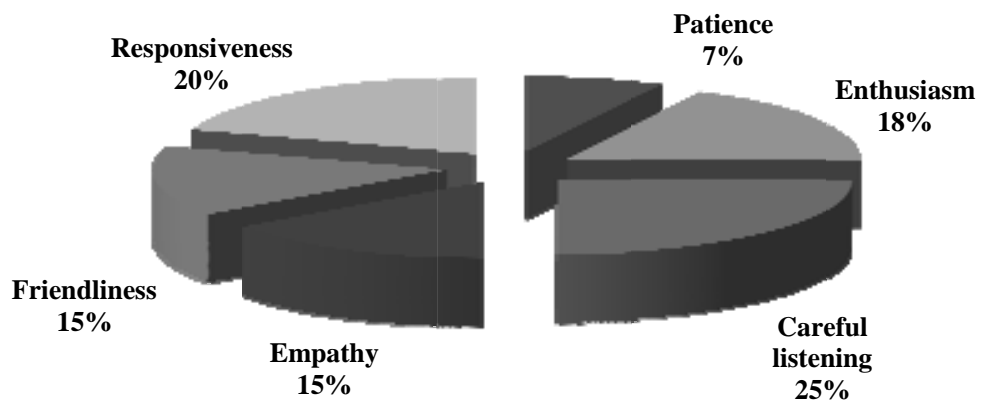

Figure 7. Analysis of Courteous Abilities of Customer Service Representative at GCB Source: Field Survey (2011).

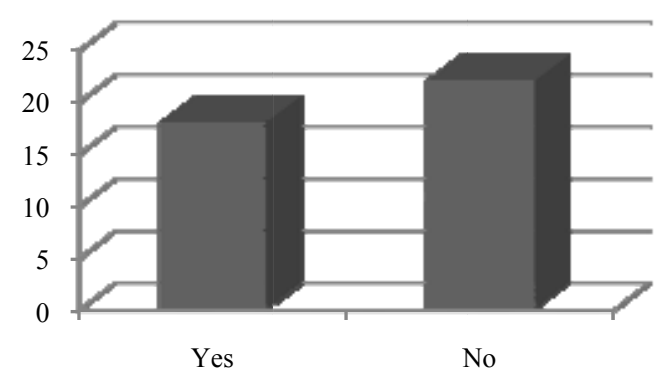

Figure 8. Analysis of Whether the Relationship between Officials of GCB and Customers is Cordial Source: Field Survey (2011).

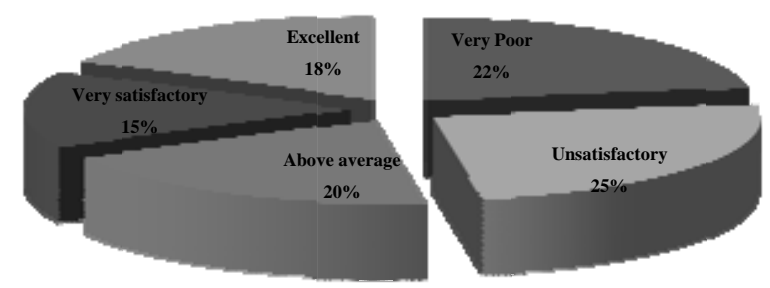

Figure 9. Analysis of Perception about Customer Service at GCB

Source: Field Survey (2011). 


\section{Appendix A}

\section{Central University College}

Customer Questionnaire

The questionnaire is designed by final year students of the Central University College and as part of our course work we are to present a research paper on the topic SERVICE QUALITY IN THE MARKETING OF FINANCIAL SERVICES (a case study of GCB Ltd). You are assured that any data provided would be treated with utmost confidentiality.

\section{Demographic Data}

Please tick $(\checkmark)$ the responses in the boxes provided.

1. Gender

Male

Female

$$
\left[\begin{array}{ll} 
& ] \\
{[} & ]
\end{array}\right.
$$

2. Profession

Manager/Executive

Teacher

Security services

Trader/Businessman

Retried

Housewife

Other (specify)

3. Age

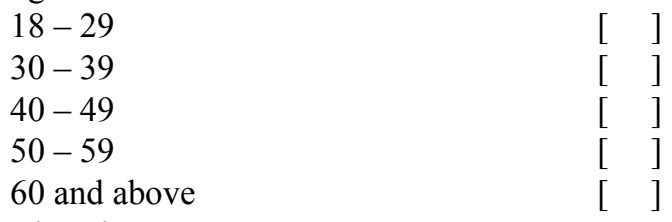

4. Education

University

Training College

Polytechnic

Middle School

Uneducated

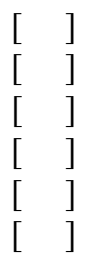

5. Income (Monthly)

Less than $₫ 500$

$ф 600-\not 1,500$

$ф 1,600-\not 2,600$

$ф 2,700-\$ 3,700$

$\$ 3,800-\not 4,800$

$\varnothing 4,800$ and above

$\begin{array}{ll}{[} & ] \\ {[} & ] \\ {[} & ] \\ {[} & ] \\ {[} & ]\end{array}$

6. Rank the following in order of importance representing your expectations of the service of the bank $(1=$ least important, 2 = less important, 3 = important, 4 = more important, 5 = most important)

\section{Dimension of Service Quality}

\section{Tangibles}

Bank has modern looking equipment

Least important

Most important

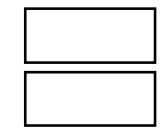

less important

[ ] $]$

$\left[\begin{array}{l}1 \\ {[}\end{array}\right]$

[ ]

[ ]

Bank facilities are visually appealing

Least important

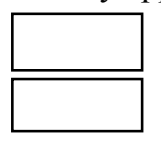

less important

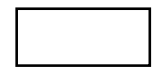
important

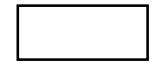

more important

Most important

\section{Reliability}

Bank performs service right the first time

Least important

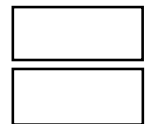

less important

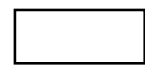

important

more important

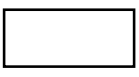

Most important
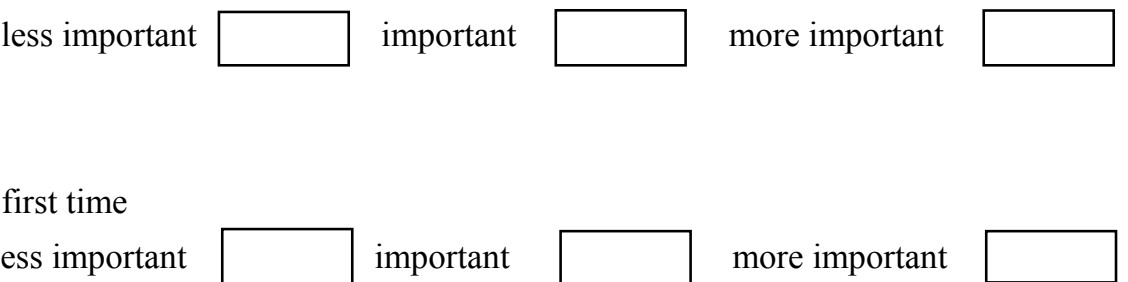

Most important 


\section{Assurance}

Employees recognise client on regular basis

Least important
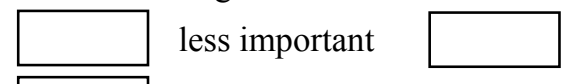

important

more important

Most important

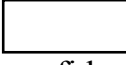

Employees inspire confidence and trust

Least important

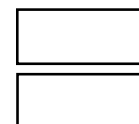

less important

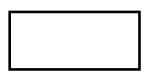

important

more important

Most important

\section{Responsiveness}

Employees give client prompt service

Least important
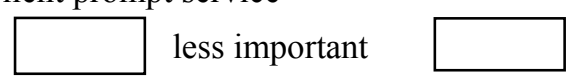

important

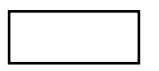

more important

Most important

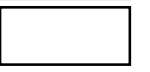

actly when service

ices will be performed

Employees tell

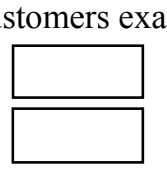

less important

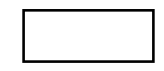

important

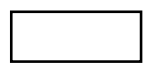

more important

Most important

\section{Empathy}

Employees deal with customers in a caring fashion

Least important

Most important

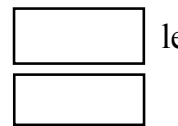

less important

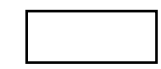

important

more important

Employees have the customers' best interest at heart

Least important
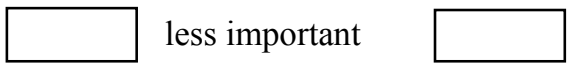

important

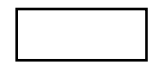

more important

Most important

7. Which of the following represent your sources of expectation?

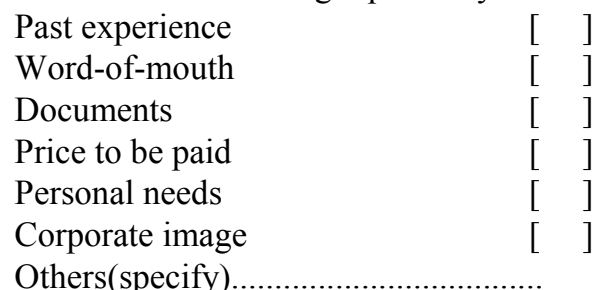

8. Are your expectations of service required met by your perceptions of service received?
Yes
No
[ ]

9. If yes, then service received if of high quality.

strongly agree $\square$ agree $\square$ neutral $\square$ disagree $\square$ strongly disagree

10. If no, then service received is of poor quality. strongly agree $\square$ agree $\square$ neutra disagree $\square$ strongly disagree

11. The reason that I deal with this bank is that they provide quality services. strongly agree agree
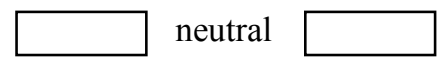

disagree

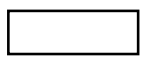
strongly disagree

12. How would you rate your assessment of the quality of services received?

Very satisfied

Satisfied

Not satisfied

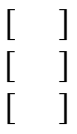

13. Would you recommend the bank to same one who seeks your advice?

Yes

No

$\left[\begin{array}{ll} & ] \\ {[} & ]\end{array}\right.$

14. If no, why? 
15. Would you encourage friends and relatives to do business with the bank?

Yes

No

[ ]

[ ]

16. Would you do business with the bank in the next few years?

Yes

No

[ ]

17. Would you say positive things about the bank to other people?

Yes

No

[ ]

18. Would you consider the bank your first choice to buy services from?

Yes

No

[ ]

[ ]

19. Which of the following actions would you take if you become dissatisfied with the services of the bank?

Complain to other consumers

Complain to external agencies

Complain to employees

Switch to a competitor

$\begin{array}{ll}{[} & ] \\ {[} & ] \\ {[} & ] \\ {[} & ]\end{array}$

Others (specify)

20. The following represent the portfolio of services I receive from the bank.

General banking/savings

Mortgages

Loan products

Insurance

Investment products and services

[ ]

[]

[ ]

Others (specify).....

21. The range of services is consistent with the latest innovations in banking services.

Strongly agree

Agree

Neutral

Disagree

Strongly disagree

$\begin{array}{ll}{[} & ] \\ {[} & ] \\ {[} & ] \\ {[} & ] \\ {[} & ]\end{array}$

